\title{
Effects of Plant Extracts on the Quality of Sous Vide Meagre (Argyrosomus regius) Fillets
}

\author{
Burcu BOZOVA ${ }^{1^{*} \mathbb{D}}$, Levent İZCI $^{2} \mathbb{D}$ \\ ${ }^{1}$ Republic Of Turkey Ministry of Agriculture and Forestry Fisherıes Research Institute Egirdir, Isparta, Turkey \\ ${ }^{2}$ University of Isparta Applied Sciences, Eğirdir Fisheries Faculty, Isparta, Turkey
}

*Corresponding Author: bozovab@gmail.com

Received 22 September 2020; Accepted 15 March 2021; Release date 01 June 2021.

How to Cite: Bozova, B., \& İzci, L. (2021). Effects of plant extracts on the quality of sous Vide Meagre (Argyrosomus regius) fillets. Acta Aquatica Turcica, 17(2), 255-266. https://doi.org/10.22392/actaquatr.798584

\begin{abstract}
This study aimed to determine the changes in the quality of sous vide meagre (Argyrosomus regius) fillets that have been treated with oregano and rosemary extracts during the cold storage $\left(4 \pm 1{ }^{\circ} \mathrm{C}\right)$. Saturated fatty acids, monounsaturated fatty acids, and polyunsaturated fatty acids dominant in meagre fish were found to be palmitic acid, oleic acid, and linoleic acid, respectively. $\mathrm{pH}$ values fluctuated during storage in sous vide samples. It was determined that total volatile basic nitrogen (TVB-N), thiobarbituric acid (TBA) and trimethylamine nitrogen (TMA-N) values did not exceed the limit values during the storage period in the Control SV, Rosemary SV, and Oregano SV groups. The total number of mesophilic aerobic bacteria (TMAB) and total psychrophilic aerobic bacteria (TPAB) on the $42^{\text {nd }}$ day did not exceed the limit values in the Control SV, Rosemary SV, and Oregano SV groups. During the cold storage, lactic acid bacteria, yeast, and mold were not detected in sous-vide cooked groups. It has been determined that rosemary and oregano extracts improve the sensory quality of the product in taste and smell.
\end{abstract}

Keywords: Meagre, Argyrosomus regius, plant extract, sous vide, quality properties

Bitki özütlerinin Sous Vide Uygulamasında Sarıăıı Balığı (Argyrosomus regius) Filetolarının Kalite Özelliklerine Etkisi

Özet

Bu çalışmada, sarıă̆ız balığı (Argyrosomus regius) filetolarının biberiye ve kekik özütleri ile muamele edilerek sous vide teknolojisinin uygulanması, soğuk muhafaza $\left(4 \pm 1{ }^{\circ} \mathrm{C}\right)$ sürecindeki bazı kalite özelliklerindeki değişimlerin belirlenmesi amaçlanmıştır. Doymuş yağ asitleri, tekli doymamış yağ asitleri ve çoklu doymamış yağ asitlerinin içinde baskın yă̆ asitlerinin sırasıyla palmitik asit, oleik asit ve linoleik asit olduğu tespit edilmiştir. Sous vide uygulanmış örneklerde $\mathrm{pH}$ değerleri muhafaza süresince dalgalı bir seyir izlemiştir. Toplam uçucu bazik azot (TVB-N), tiyobarbitürik asit (TBA) ve trimetilamin azot (TMA-N) değerlerinin, sous vide uygulanan Kontrol SV, Biberiye SV ve Kekik SV gruplarında muhafaza süresince limit değerleri aşmadığı saptanmıştır. Kontrol SV, Biberiye SV ve Kekik SV gruplarında 42. gün toplam mezofilik aerobik bakteri (TMAB) sayısı ve toplam psikrofilik aerobik bakteri (TPAB) sayısı limit değerlerini aşmamıştır. Depolama süresince sous vide uygulanan gruplarda laktik asit bakterileri, maya ve küf tespit edilmemiştir. Biberiye ve kekik özütlerinin tat ve koku açısından ürünün duyusal kalitesini geliştirdiği belirlenmiştir.

Anahtar Kelimeler: Sarıăız, Argyrosomus regius, bitkisel özüt, sous vide, kalite özellikleri

\section{INTRODUCTION}

Fish is an important food source for human health. Average fish consumption per capita in Turkey decreased from $8.0 \mathrm{~kg}$ in 2000 to $6.3 \mathrm{~kg}$ in 2019 (BSGM, 2020). Fish consumption per capita in Turkey is far below the average fish consumed globally (FAO, 2020). Considering this situation, it is of great importance to encourage fish consumption. Fish meat, which is easy to chew and digest, is a good nutrient that can be easily consumed by all society segments (Öksüz et al., 2017). Fish should be delivered to consumers not only in the fishing area but also in every region. Fish meat is susceptible to spoilage due to poor connective tissue, high enzyme activity, $\mathrm{pH}$ value, and high water content (Ufuk and Sarımehmetoğlu, 2016).

Meagre has attracted attention with its increasing production amount in our country and Europe in recent years (Bodur, 2018). Meagre has attractive features for the market with its good processing efficiency, low-fat content, excellent taste, and tight texture (Monfort, 2010). 
In the last ten years, eating habits have changed, and accordingly, the ready-made food sector has also changed. The family structure has changed and the number of people living alone has increased. As the more educated conscious consumers of today's women, they turn to health-oriented and prepared foods in a short time (Monfort, 2010).

In recent years, the demand for fresh, high-quality, preservative-free foods that can be prepared in a short time has been increasing. Thus sous vide technology is frequently used in new food products with a long shelf life, pasteurized with minimal processing methods at lower temperatures, and stored in refrigerator conditions (Betts and Gaze, 1995). Sous vide cooking refers to a process in which vacuum-packed foods are immersed in a temperature-controlled water bath or cooked in a steam oven (BCCDC, 2016). Sous vide means "under vacuum" in French (Beauchemin, 1990). Unlike traditional cooking methods, in the sous vide method, food is cooked longer at lower temperatures (usually below $\left.100^{\circ} \mathrm{C}\right)$ (Schellekens, 1996).

Sous vide products can be served by heating in a hot water bath or microwave oven. This method is a useful method for preserving perishable foods such as fish and easy consumption (Mol and Özturan, 2009). Long shelf life sous vide products are increasingly being used in catering companies, restaurants, and homes (NSW, 2018). Since pasteurization only destroys vegetative cells, considering the spores' presence, the shelf life varies between 6-42 days (Schellekens, 1996). The reason why sous vide products are appreciated in terms of taste is that they have the closest aroma to fresh produce (Garcia-Linares et al., 2004). Applied low temperatures preserve the moisture, flavor, and colour of foods (BCCDC, 2016). A strict cold chain follow-up is required for sous vide products. The safety of sous vide products throughout the shelf life depends on the initial microbiological load of the raw material and the suitability of the cold storage conditions (Beauchemin, 1990).

With the increasing awareness of consumers, natural additives instead of synthetic chemical additives in the protection of foods have become popular (Holley and Patel, 2005). In terms of the modern food industry market, essential oils and bioactive compounds obtained from aromatic plants can be a good industrial raw material, especially for functional food production (Giacometti et al., 2018). Rosemary, a member of the Laminaceae family, is the most studied herb. Rosemary extract was the first herb to be marketed as a natural antioxidant. Oregano, which belongs to the same family, is of interest to many researchers regarding its antioxidant potential (Lagouri and Boskou, 1996).

Fish is a popular raw material for sous vide (Garcia-Linares et al., 2004). Several studies have been conducted on the shelf life and sensory properties of sous vide fish products (Gonzalez-Fandos et al. 2004; Garcia-Linares et al., 2004; Gonzalez-Fandos et al., 2005; Diaz et al., 2009; Mol et al., 2012; Çetinkaya 2013; Ibarra et al., 2013; Espinosa et al. 2015; Doğruyol and Mol, 2016; Altıkaya 2016; Kato et al., 2017; İnanlı and Yaz, 2020).

This study aimed to apply sous vide technology on meagre's fillets with different plant extracts and determine the chemical, microbiological, and sensory quality changes during the cold storage.

\section{MATERIAL and METHODS \\ Sample preparation}

The meagre, which were purchased from a local retailer, an average of $36.90 \pm 0.16 \mathrm{~cm}$ length and $488.04 \pm 6.33 \mathrm{~g}$ weight, were thoroughly washed with cooled water, then the head, viscera, and skin were removed and the skinless fillets were obtained.

\section{Obtaining plant extracts and preparation of samples}

According to Baydar (2013), El-Hanafy et al. (2011), and Bozkurt (2006), plant extracts were obtained with some modifications. Rosemary and oregano spices were infused at the rate of $5 \%(\mathrm{w} / \mathrm{v}$, spice/distilled water) in $95 \pm 1{ }^{\circ} \mathrm{C}$ distilled water for 5 minutes. At the end of the time, the plant and liquid extract were separated. Skinless fillets at a ratio of 1:1 (w/v, fillet /extract) were immersed in $5 \%$ (w:v) chilled rosemary and oregano liquid extract in a refrigerator at $4 \pm 1{ }^{\circ} \mathrm{C}$ for 30 minutes. Fillets drained from liquid extract were vacuum-packed and cooked in a water bath at $85{ }^{\circ} \mathrm{C}$ for 36 minutes with the sous vide method (Betts and Gaze,1995). Sample groups consisted of Raw fish (fish fillet), Control SV (Sous vide), Rosemary SV (Rosemary extract-treated fish fillet with sous vide), and Oregano SV (Oregano extract-treated fish fillet with sous vide) groups.

\section{Chemical analysis}

Moisture analysis (Kern DBS Moisture Analyzer), crude protein (AOAC, 2000), crude fat (Bligh and Dyer, 1959), and crude ash (Ash Furnace Core TS 500) analysis (AOAC, 2002a) were made. 
Fatty acid composition analysis was performed by the Innovative Technologies Application and Research Center (YETEM) in the Süleyman Demirel University (SDU). After crude fat extraction from the samples (Bligh and Dyer, 1959), the methylation process was carried out according to AOAC (2002b).

Also, pH (Varlık et al., 2007), thiobarbituric acid (TBA, mg MDA $/ \mathrm{kg}$ ) (Erkan and Özden, 2008; Erkan et al., 2009), total volatile basic nitrogen (TVB-N, mg/100g) (Nicholas, 2003), trimethylamine nitrogen (TMA-N, mg/100g) (Varlık et al., 2007; Schormüller, 1968) analyzes were made.

\section{Microbiological analysis}

$10 \mathrm{~g}$ sample and $90 \mathrm{ml}$ sterile peptone water homogenized with stomacher under aseptic conditions. Dilutions were made up to $10^{-6}$ and cultivation was made according to the pour plating method (Arslan et al., 1997; Harrigan and McCance, 1976). PCA was used for TMAB and TPAB. Plates were incubated for TMAB at $30 \pm 1{ }^{\circ} \mathrm{C}$ for 72 hours (Varlik et al., 1993), and TPAB at $4 \pm 1{ }^{\circ} \mathrm{C}$ for 15 days (Arslan et al., 1997). Lactic acid bacteria were determined using MRS agar incubated at $30{ }^{\circ} \mathrm{C}$ for 5 days (Genç et al., 2013). YGC agar plates were incubated at $30{ }^{\circ} \mathrm{C}$ for 3-5 days for yeast and mold (Amariei et al., 2016). Results are given in $\log \mathrm{cfu} / \mathrm{g}$.

\section{Sensory analysis}

The hedonic scale reported by Altuğ and Elmacı (2005) and Çetinkaya (2013) was modified and used in the evaluation of sensory characteristics. Sous vide meagre samples were evaluated in terms of color, odor, appearance, texture, taste, and general evaluation. 8 panelists were asked to assess between 1 and 10. Samples scoring less than $\leq 4.0$ were considered impaired before evaluating the sensory experiment samples heated in the microwave oven and served with plain crackers and water.

\section{Statistical analysis}

The data obtained in the study were subjected to variance analysis (one-way ANOVA) with the SPSS 18.0 statistical package program. The means of important variance sources were compared with the Duncan Multiple Comparison Test at $\mathrm{P}=0.05$ confidence interval.

\section{RESULTS and DISCUSSION}

Chemical composition analysis has been made in all samples and is given in Table 1. It was determined that the samples' moisture value decreased significantly compared to raw fish $(\mathrm{P}<0.05)$. While the protein values of the groups treated with oregano and rosemary extract were statistically similar, it was found to be significantly higher than the other groups $(\mathrm{P}<0.05)$.

Table 1. Chemical composition of raw fish and sous vide samples *

\begin{tabular}{lllll}
\hline \hline $\mathbf{( \% )}$ & Raw fish & Control SV & Rosemary SV & Oregano SV \\
\hline Moisture & $79.70 \pm 0.51^{\mathrm{a}}$ & $77.72 \pm 0.41^{\mathrm{b}}$ & $75.07 \pm 0.14^{\mathrm{c}}$ & $75.38 \pm 0.46^{\mathrm{c}}$ \\
Crude fat & $1.06 \pm 0.14^{\mathrm{bc}}$ & $1.31 \pm 0.02^{\mathrm{ab}}$ & $1.03 \pm 0.09^{\mathrm{c}}$ & $1.57 \pm 0.01^{\mathrm{a}}$ \\
Crude protein & $18.30 \pm 0.15^{\mathrm{c}}$ & $20.26 \pm 0.46^{\mathrm{b}}$ & $21.59 \pm 0.20^{\mathrm{a}}$ & $21.74 \pm 0.10^{\mathrm{a}}$ \\
Crude ash & $1.02 \pm 0.01^{\mathrm{a}}$ & $0.99 \pm 0.01^{\mathrm{a}}$ & $0.86 \pm 0.01^{\mathrm{b}}$ & $0.95 \pm 0.04^{\mathrm{a}}$ \\
\hline *There is a statistical difference between the means with different letters on the same line $(\mathrm{P}<0.05)$
\end{tabular}

The significant decrease in moisture value observed after sous vide is similar to the results of the studies conducted by Garcia-Linares et al. (2004), Gonzalez-Fandos et al. (2005), Mol et al. (2012), and Çetinkaya et al. (2015). The crude protein compared to the raw sample after sous vide is similar to Garcia-Linares et al. (2004), Mol et al. (2012), and Çetinkaya et al. (2015) studies and not similar to Ramos et al. (2016) study. Crude fat value increased significantly in the Oregano SV group after sous vide $(\mathrm{P}<0.05)$, while it did not significantly change in the Control SV and Rosemary SV groups $(\mathrm{P}>0.05)$. In general, with the crude ash results obtained in our study, Mol et al. (2012) and Çetinkaya (2013) 's results are similar.

According to the fatty acid composition analysis results, it was determined that 10 of these fatty acids were saturated (SFA), 6 were monounsaturated (MUFA) and 9 were polyunsaturated (PUFA). SFA, MUFA, and PUFA dominant in meagre fish were found to be palmitic acid, oleic acid, and linoleic acid, respectively. $\Sigma$ SFA, $\Sigma$ MUFA, $\Sigma$ PUFA, $\Sigma($ DHA+EPA) and $\Sigma \mathrm{n} 3 / \Sigma \mathrm{n} 6$ in raw fish were determined at $19.97 \pm 0.02 \%, 27.35 \pm 0.01 \%, 34.36 \pm 0.00 \%, 9.10 \pm 0.00$ and $0.49 \pm 0.00$, respectively.

In the sous vide samples were determined that palmitic acid (C16:0) between $12.68 \pm 0.01 \%$ and $17.33 \pm 0.02 \%$, oleic acid (C18:1n-9c) between $20.07 \pm 0.01 \%$ and $28.26 \pm 0.01 \%$, linoleic acid (C18:2n- 
6c) between $15.28 \pm 0.00 \%$ and $18.75 \pm 0.01 \%$ during the storage. Changes in $\Sigma$ SFA, $\Sigma$ MUFA, and $\Sigma$ PUFA values at the end of storage were found to be significant $(\mathrm{P}<0.05)$ in all sous vide samples. The $\Sigma \mathrm{n} 3 / \Sigma \mathrm{n} 6$ was determined as the lowest $0.45 \pm 0.00$ and the highest $0.84 \pm 0.00$ in sous vide sample groups during storage (Table 2). It was determined that the amount of eicosapentaenoic acid (C20:5n3) (EPA) varied between $0.96 \pm 0.02 \%$ and $1.62 \pm 0.01 \%$ and docosahexaenoic acid (C22:6n-3) (DHA) varied between $5.17 \pm 0.00 \%$ and $13.79 \pm 0.00 \%$ during storage.

In our study, it was determined that the dominant SFA and MUFA are palmitic acid and oleic acid similar to the Grigorakis et al. (2011), Giogios et al. (2013), Martelli et al. (2013), Mesa et al. (2014), Saavedra et al. (2015), Bilgin et al. (2016) and Fountoulaki et al. (2017) studies. Similar to this study, Giogios et al. (2013), Saavedra et al. (2015), and Bilgin et al. (2016) studies, it was determined that C18:2n-6 and C22:6n-3 were the most prominent fatty acids among PUFA. Similar to our study, Çetinkaya (2013) found a significant change in PUFA at the end of storage in sous vide rainbow trout samples treated with rosemary and thyme. 
Tablo 2. Fatty acid composition of the samples $(\%)^{*}$

\begin{tabular}{|c|c|c|c|c|c|c|}
\hline Group & $\begin{array}{c}\text { Fatty } \\
\text { Acids } \\
\text { Day } \\
\end{array}$ & $\Sigma$ SFA & $\Sigma$ MUFA & $\Sigma$ PUFA & $\Sigma n 3 / \Sigma n 6$ & $($ DHA+EPA $)$ \\
\hline \multirow{7}{*}{ 造 } & 0 & $20.82 \pm 0.01^{\mathrm{e}}$ & $31.40 \pm 0.02^{\mathrm{e}}$ & $32.37 \pm 0.00^{\mathrm{f}}$ & $0.59 \pm 0.00^{\mathrm{b}}$ & $9.55 \pm 0.00^{\mathrm{d}}$ \\
\hline & 7 & $20.81 \pm 0.02^{\mathrm{e}}$ & $31.35 \pm 0.02^{\mathrm{e}}$ & $32.42 \pm 0.08^{\mathrm{f}}$ & $0.59 \pm 0.01^{\mathrm{b}}$ & $9.57 \pm 0.00^{c}$ \\
\hline & 14 & $20.44 \pm 0.01^{\mathrm{f}}$ & $30.84 \pm 0.02^{\mathrm{f}}$ & $39.18 \pm 0.02^{\mathrm{a}}$ & $0.84 \pm 0.00^{\mathrm{a}}$ & $15.23 \pm 0.01^{\mathrm{a}}$ \\
\hline & 21 & $22.70 \pm 0.00^{\mathrm{d}}$ & $34.95 \pm 0.01^{\mathrm{d}}$ & $33.42 \pm 0.01^{\mathrm{e}}$ & $0.56 \pm 0.00^{\mathrm{d}}$ & $9.33 \pm 0.00^{\mathrm{e}}$ \\
\hline & 28 & $24.77 \pm 0.00^{\mathrm{a}}$ & $35.05 \pm 0.03^{\mathrm{c}}$ & $34.44 \pm 0.01^{\mathrm{b}}$ & $0.58 \pm 0.00^{\mathrm{c}}$ & $10.05 \pm 0.01^{b}$ \\
\hline & 35 & $23.43 \pm 0.00^{c}$ & $35.66 \pm 0.00^{\mathrm{b}}$ & $33.89 \pm 0.02^{\mathrm{c}}$ & $0.52 \pm 0.00^{\mathrm{f}}$ & $8.95 \pm 0.00^{\mathrm{g}}$ \\
\hline & 42 & $23.49 \pm 0.00^{\mathrm{b}}$ & $36.25 \pm 0.02^{\mathrm{a}}$ & $33.58 \pm 0.02^{\mathrm{d}}$ & $0.54 \pm 0.00^{\mathrm{e}}$ & $9.09 \pm 0.00^{f}$ \\
\hline \multirow{7}{*}{ 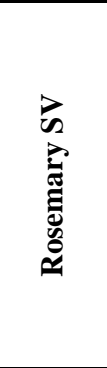 } & $\mathbf{0}$ & $20.78 \pm 0.01^{\mathrm{f}}$ & $28.68 \pm 0.02^{f}$ & $35.87 \pm 0.02^{\mathrm{b}}$ & $0.49 \pm 0.00^{\mathrm{e}}$ & $9.40 \pm 0.01^{\mathrm{c}}$ \\
\hline & 7 & $20.34 \pm 0.03^{\mathrm{g}}$ & $28.10 \pm 0.02^{\mathrm{g}}$ & $34.25 \pm 0.00^{\mathrm{d}}$ & $0.45 \pm 0.00^{\mathrm{f}}$ & $8.37 \pm 0.01^{\mathrm{f}}$ \\
\hline & 14 & $23.75 \pm 0.04^{\mathrm{d}}$ & $35.81 \pm 0.01^{\mathrm{c}}$ & $32.98 \pm 0.03^{\mathrm{f}}$ & $0.51 \pm 0.00^{\mathrm{d}}$ & $8.56 \pm 0.01^{\mathrm{e}}$ \\
\hline & 21 & $24.48 \pm 0.01^{\mathrm{b}}$ & $36.48 \pm 0.00^{\mathrm{b}}$ & $33.16 \pm 0.00^{\mathrm{e}}$ & $0.52 \pm 0.00^{c}$ & $8.63 \pm 0.00^{\mathrm{d}}$ \\
\hline & 28 & $24.34 \pm 0.02^{\mathrm{c}}$ & $34.82 \pm 0.01^{\mathrm{e}}$ & $34.58 \pm 0.03^{\mathrm{c}}$ & $0.57 \pm 0.00^{\mathrm{b}}$ & $10.03 \pm 0.03^{\mathrm{b}}$ \\
\hline & 35 & $22.83 \pm 0.00^{\mathrm{e}}$ & $35.58 \pm 0.00^{\mathrm{d}}$ & $37.09 \pm 0.02^{\mathrm{a}}$ & $0.66 \pm 0.00^{\mathrm{a}}$ & $11.95 \pm 0.00^{\mathrm{a}}$ \\
\hline & 42 & $27.56 \pm 0.02^{\mathrm{a}}$ & $36.90 \pm 0.03^{\mathrm{a}}$ & $27.81 \pm 0.02^{\mathrm{g}}$ & $0.45 \pm 0.00^{\mathrm{f}}$ & $6.13 \pm 0.01^{\mathrm{g}}$ \\
\hline \multirow{7}{*}{ 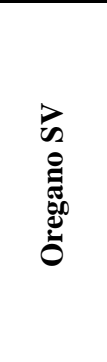 } & $\mathbf{0}$ & $21.05 \pm 0.01^{\mathrm{g}}$ & $31.78 \pm 0.04^{\mathrm{g}}$ & $32.30 \pm 0.05^{\mathrm{f}}$ & $0.587 \pm 0.00^{\mathrm{b}}$ & $9.54 \pm 0.00^{b}$ \\
\hline & 7 & $21.18 \pm 0.01^{\mathrm{f}}$ & $34.73 \pm 0.02^{\mathrm{e}}$ & $34.30 \pm 0.04^{\mathrm{c}}$ & $0.540 \pm 0.00^{\mathrm{d}}$ & $9.43 \pm 0.01^{\mathrm{c}}$ \\
\hline & 14 & $23.41 \pm 0.01^{\mathrm{e}}$ & $36.36 \pm 0.00^{\mathrm{b}}$ & $33.85 \pm 0.02^{\mathrm{d}}$ & $0.511 \pm 0.00^{\mathrm{f}}$ & $8.76 \pm 0.01^{\mathrm{d}}$ \\
\hline & 21 & $24.47 \pm 0.04^{\mathrm{c}}$ & $36.69 \pm 0.04^{\mathrm{a}}$ & $32.75 \pm 0.00^{\mathrm{e}}$ & $0.507 \pm 0.00^{\mathrm{g}}$ & $8.38 \pm 0.01^{\mathrm{e}}$ \\
\hline & 28 & $24.71 \pm 0.01^{\mathrm{a}}$ & $34.96 \pm 0.02^{\mathrm{d}}$ & $32.79 \pm 0.00^{\mathrm{e}}$ & $0.530 \pm 0.00^{\mathrm{e}}$ & $8.81 \pm 0.02^{\mathrm{d}}$ \\
\hline & 35 & $23.98 \pm 0.01^{\mathrm{d}}$ & $35.55 \pm 0.00^{\mathrm{c}}$ & $34.74 \pm 0.02^{\mathrm{a}}$ & $0.579 \pm 0.00^{\mathrm{c}}$ & $10.16 \pm 0.00^{\mathrm{a}}$ \\
\hline & 42 & $24.60 \pm 0.01^{\mathrm{b}}$ & $33.71 \pm 0.05^{\mathrm{f}}$ & $34.44 \pm 0.08^{\mathrm{b}}$ & $0.589 \pm 0.00^{\mathrm{a}}$ & $10.20 \pm 0.03^{\mathrm{a}}$ \\
\hline
\end{tabular}

${ }^{*}$ The means with different letters in the same column are significantly different $(\mathrm{P}<0.05)$.

In the post-mortem period, $\mathrm{pH}$ rises with the decomposition of nitrogenous compounds depending on microbiological activity. $\mathrm{pH}$ change is also affected by the storage temperature and above 7.1 indicates deterioration (Hernandez et al., 2009). In the study, the $\mathrm{pH}$ value of raw fish was determined as 6.71 \pm 0.03 . The Control SV's pH value, Rosemary SV and Oregano SV samples were measured as $6.87 \pm 0.02,6.90 \pm 0.01,6.96 \pm 0.01$ on day 0 , respectively. $\mathrm{pH}$ were fluctuated during storage in sous vide samples (Table $3,4,5)$. Bolat et al. (2019) applied sous vide technology $\left(90{ }^{\circ} \mathrm{C}, 10 \mathrm{~min}\right.$ ) to sea bass, by adding laurel and curcuma. It has been reported that the $\mathrm{pH}$ value of sous vide samples to which laurel and curcuma were added during storage varied between 6.61-6.91 and 6.64-6.86, respectively.

Total volatile basic nitrogen (TVB-N) is one of the most commonly used methods for determining fish meat spoilage (Ruiz-Capillas and Moral, 2001). It is not preferred to have a TVB-N value above $20 \mathrm{mg} \mathrm{N} / 100 \mathrm{~g}$ TVB-N for fish to be used in canned fish products and $30 \mathrm{mg}$ N/100 g TVB-N for frozen tuna fish (Connell, 1995). TVB-N value in raw fish samples was initially determined as $14.54 \pm 0.22 \mathrm{mg} / 100 \mathrm{~g}$. It has been determined that TVB-N values did not exceed the limit value in the sous vide samples during storage. According to a study the use of rosemary extract alone or in combination with nisin reduces the TVB-N value by 14-38\% during cold storage of raw Trachinotus ovatus fillets (Gao vd., 2014). Çetinkaya (2013) stated that the limit values were not exceeded in all rainbow trout sous vide samples during storage. It has been reported that in the sous vide group which thyme was applied, the change range in the TVB-N value was smaller and the product showed a more stable structure (Çetinkaya, 2013). Kenar et al. (2010) investigated the antimicrobial and antioxidant effects of rosemary and sage extracts, sardine fish were immersed in these extracts (4 min) and stored at $3^{\circ} \mathrm{C}$ by vacuum packaging. It has been stated that the application of rosemary and sage is effective on TVB-N value. In the sea bass sous vide study, it was stated that control sous vide, laurel and curcuma added sous vide samples were of good quality in terms of TVB-N values during storage and the limit values were not exceeded (Bolat et al., 2019). Similar results were obtained in our study. 
According to these results, it can be said that sous vide processing, oregano and rosemary extract are effective in retarding the increase in TVB-N value (Table 3, 4, 5).

The amount of TMAO in fish muscle tissue varies according to the species, season and fishing location. TMA, formed by the bacterial breakdown of TMAO, a volatile compound, has a very characteristic "fishy" odour (Huss, 2007). It is stated that the TMA-N value should be between $1 \mathrm{mg}$ $\mathrm{N} / 100 \mathrm{~g}$ and $8 \mathrm{mg} \mathrm{N} / 100 \mathrm{~g}$ in seafood suitable for consumption (Varlık et al., 1993). TMA-N value in raw fish is determined as $2.66 \pm 0.01 \mathrm{mg} / 100 \mathrm{~g}$. In Control SV, Rosemary SV and Oregano SV group samples, the TMA-N value, which was $2.57 \pm 0.08 ; 2.63 \pm 0.03$ and $3.04 \pm 0.07 \mathrm{mg} / 100 \mathrm{~g}$ on day 0 , respectively, increased to $2.78 \pm 0.02,2.90 \pm 0.04$ and $4.16 \pm 0.03 \mathrm{mg} / 100 \mathrm{~g}$ values significantly on day $42(\mathrm{P}<0.05)$. Nieva-Echevarria et al. (2017) indicated that TMA can be used in a limited way as an indicator of freshness in cultured fish. Bolat et al. (2019) stated that the sea bass sous vide samples did not exceed the limit values in terms of TMA-N values during storage. Although TMA-N values fluctuate during storage in sous vide samples, they did not exceed the limit value in this study. Sous vide process is thought to be effective in the TMA-N value (Table $3,4,5$ ).

Oxidative rancidity begins when oxygen forms hydroperoxide with unsaturated fatty acids, especially in fatty fish (Connell, 1995). The limit value consumed in TBA terms is specified as $8 \mathrm{mg}$ MDA/kg (Özden ve Erkan, 2006; Ramos et al., 2016). TBA in raw fish samples was determined to be $0.52 \pm 0.13 \mathrm{mg} \mathrm{MDA} / \mathrm{kg}$. TBA value fluctuated in all sous vide sample groups during storage. Due to the oxygen-free environment provided by vacuum packaging and the low fat content of meagre, high TBA values may not have been observed in sous vide samples. When the TBA values in the sous vide sample groups were examined, it was seen that the TBA values in the Rosemary SV and Oregano SV samples were lower than the Control SV values. Nissen et al. (2004), Sebranek et al. (2005), Tironi et al. (2010), Gao et al. (2014), Uçak et al. (2011) and Çetinkaya (2013) in studies found similar results. The application of rosemary and oregano extract in the meagre sous vide process can be said that retarding effect on TBA values. Also, It was determined that the limit value was not exceeded in all sous video sample groups during storage (Table 3, 4, 5).

Table 3. Chemical and microbiological analysis results of the Control SV group

\begin{tabular}{lcccccccc}
\hline \hline Day & $\mathbf{p H}$ & $\begin{array}{c}\text { TVB-N, } \\
\mathbf{m g} / \mathbf{1 0 0} \mathbf{g}\end{array}$ & $\begin{array}{c}\text { TBA, } \\
\mathbf{m g ~ M D A} / \mathbf{k g}\end{array}$ & $\begin{array}{c}\text { TMA-N, } \\
\mathbf{m g} / \mathbf{1 0 0} \mathbf{g}\end{array}$ & $\begin{array}{c}\text { TMAB } \\
\text { log cfu/g }\end{array}$ & $\begin{array}{c}\text { TPAB } \\
\mathbf{l o g} \mathbf{c f u} / \mathbf{g}\end{array}$ & $\begin{array}{c}\text { LAB } \\
\text { log } \\
\mathbf{c f u} / \mathbf{g}\end{array}$ & $\begin{array}{c}\text { Yeast- } \\
\text { Mold } \\
\text { log cfu/g }\end{array}$ \\
\hline 0 & $6.87 \pm 0.02^{\mathrm{ab}}$ & $15.80 \pm 0.61^{\mathrm{b}}$ & $0.25 \pm 0.03^{\mathrm{c}}$ & $2.57 \pm 0.08^{\mathrm{c}}$ & $<1.0$ & $<1.0$ & $<1.0$ & $<1.0$ \\
7 & $6.89 \pm 0.01^{\mathrm{ab}}$ & $17.56 \pm 0.37^{\mathrm{a}}$ & $0.47 \pm 0.06^{\mathrm{b}}$ & $3.20 \pm 0.03^{\mathrm{a}}$ & $<1.0$ & $<1.0$ & $<1.0$ & $<1.0$ \\
14 & $6.85 \pm 0.01^{\mathrm{b}}$ & $17.82 \pm 0.30^{\mathrm{a}}$ & $0.60 \pm 0.01^{\mathrm{ab}}$ & $2.40 \pm 0.01^{\mathrm{de}}$ & $<1.0$ & $<1.0$ & $<1.0$ & $<1.0$ \\
21 & $6.85 \pm 0.02^{\mathrm{b}}$ & $17.48 \pm 0.22^{\mathrm{a}}$ & $0.47 \pm 0.05^{\mathrm{b}}$ & $2.32 \pm 0.07^{\mathrm{e}}$ & $<1.0$ & $<1.0$ & $<1.0$ & $<1.0$ \\
28 & $6.79 \pm 0.02^{\mathrm{c}}$ & $17.65 \pm 0.14^{\mathrm{a}}$ & $0.66 \pm 0.06^{\mathrm{a}}$ & $2.60 \pm 0.06^{\mathrm{c}}$ & $<1.0$ & $<1.0$ & $<1.0$ & $<1.0$ \\
35 & $6.88 \pm 0.01^{\mathrm{ab}}$ & $15.97 \pm 0.22^{\mathrm{b}}$ & $0.67 \pm 0.03^{\mathrm{a}}$ & $2.49 \pm 0.06^{\mathrm{cd}}$ & $<1.0$ & $<1.0$ & $<1.0$ & $<1.0$ \\
42 & $6.91 \pm 0.01^{\mathrm{a}}$ & $16.39 \pm 0.14^{\mathrm{b}}$ & $0.71 \pm 0.08^{\mathrm{a}}$ & $2.78 \pm 0.02^{\mathrm{b}}$ & $2.76 \pm 0.05$ & $2.88 \pm 0.02$ & $<1.0$ & $<1.0$ \\
\hline \hline
\end{tabular}

* The means with different letters in the same column are significantly different $(\mathrm{P}<0.05)$. 
Table 4. Chemical and microbiological analysis results of the Rosemary SV group

\begin{tabular}{lcccccccc}
\hline \hline Day & $\mathbf{p H}$ & $\begin{array}{c}\text { TVB-N, } \\
\mathbf{m g} / \mathbf{1 0 0} \mathbf{g}\end{array}$ & $\begin{array}{c}\text { TBA, } \\
\mathbf{m g ~ M D A} / \mathbf{k g}\end{array}$ & $\begin{array}{c}\text { TMA-N, } \\
\mathbf{m g} / \mathbf{1 0 0} \mathbf{g}\end{array}$ & $\begin{array}{c}\text { TMAB } \\
\mathbf{l o g} \mathbf{c f u} / \mathbf{g}\end{array}$ & $\begin{array}{c}\text { TPAB } \\
\mathbf{l o g} \mathbf{c f u} / \mathbf{g}\end{array}$ & $\begin{array}{c}\text { LAB } \\
\mathbf{l o g} \\
\mathbf{c f u} / \mathbf{g}\end{array}$ & $\begin{array}{c}\text { Yeast- } \\
\text { Mold } \\
\mathbf{l o g} \text { cfu/g }\end{array}$ \\
\hline 0 & $6.90 \pm 0.01^{\mathrm{bc}}$ & $14.62 \pm 0.15^{\mathrm{bc}}$ & $0.17 \pm 0.02^{\mathrm{b}}$ & $2.63 \pm 0.03^{\mathrm{c}}$ & $<1.0$ & $<1.0$ & $<1.0$ & $<1.0$ \\
7 & $6.99 \pm 0.00^{\mathrm{a}}$ & $14.71 \pm 0.22^{\mathrm{bc}}$ & $0.28 \pm 0.02^{\mathrm{ab}}$ & $2.99 \pm 0.05^{\mathrm{ab}}$ & $<1.0$ & $<1.0$ & $<1.0$ & $<1.0$ \\
14 & $6.92 \pm 0.01^{\mathrm{b}}$ & $15.88 \pm 0.39^{\mathrm{a}}$ & $0.18 \pm 0.03^{\mathrm{b}}$ & $2.56 \pm 0.09^{\mathrm{c}}$ & $<1.0$ & $<1.0$ & $<1.0$ & $<1.0$ \\
21 & $6.86 \pm 0.01^{\mathrm{c}}$ & $15.38 \pm 0.14^{\mathrm{ab}}$ & $0.23 \pm 0.02^{\mathrm{ab}}$ & $2.18 \pm 0.01^{\mathrm{d}}$ & $<1.0$ & $<1.0$ & $<1.0$ & $<1.0$ \\
28 & $6.88 \pm 0.02^{\mathrm{bc}}$ & $15.21 \pm 0.30^{\mathrm{ab}}$ & $0.18 \pm 0.02^{\mathrm{b}}$ & $3.20 \pm 0.12^{\mathrm{a}}$ & $<1.0$ & $<1.0$ & $<1.0$ & $<1.0$ \\
35 & $6.91 \pm 0.02^{\mathrm{b}}$ & $14.20 \pm 0.30^{\mathrm{c}}$ & $0.18 \pm 0.03^{\mathrm{b}}$ & $2.74 \pm 0.13^{\mathrm{bc}}$ & $<1.0$ & $<1.0$ & $<1.0$ & $<1.0$ \\
42 & $6.93 \pm 0.02^{\mathrm{b}}$ & $14.88 \pm 0.15^{\mathrm{bc}}$ & $0.38 \pm 0.18^{\mathrm{a}}$ & $2.90 \pm 0.04^{\mathrm{b}}$ & $5.69 \pm 0.03$ & $5.11 \pm 0.03$ & $<1.0$ & $<1.0$ \\
\hline \hline
\end{tabular}

* The means with different letters in the same column are significantly different $(\mathrm{P}<0.05)$.

Table 5. Chemical and microbiological analysis results of the Oregano SV group

\begin{tabular}{lcccccccc}
\hline \hline Day & $\mathbf{p H}$ & $\begin{array}{c}\text { TVB-N, } \\
\mathbf{m g} / \mathbf{1 0 0} \mathbf{g}\end{array}$ & $\begin{array}{c}\text { TBA, } \\
\mathbf{m g ~ M D A} / \mathbf{k g}\end{array}$ & $\begin{array}{c}\text { TMA-N, } \\
\mathbf{m g} / \mathbf{1 0 0} \mathbf{g}\end{array}$ & $\begin{array}{c}\text { TMAB } \\
\mathbf{l o g} \mathbf{c f u} / \mathbf{g}\end{array}$ & $\begin{array}{c}\text { TPAB } \\
\mathbf{l o g} \mathbf{c f u} / \mathbf{g}\end{array}$ & $\begin{array}{c}\text { LAB } \\
\mathbf{l o g} \\
\mathbf{c f u} / \mathbf{g}\end{array}$ & $\begin{array}{c}\text { Yeast- } \\
\text { Mold } \\
\mathbf{l o g} \mathbf{c f u} / \mathbf{g}\end{array}$ \\
\hline 0 & $6.96 \pm 0.01^{\mathrm{a}}$ & $14.87 \pm 0.39^{\mathrm{bcd}}$ & $0.20 \pm 0.01^{\mathrm{ab}}$ & $3.04 \pm 0.07^{\mathrm{c}}$ & $<1.0$ & $<1.0$ & $<1.0$ & $<1.0$ \\
7 & $6.89 \pm 0.01^{\mathrm{b}}$ & $14.54 \pm 0.22^{\mathrm{cd}}$ & $0.24 \pm 0.05^{\mathrm{ab}}$ & $2.53 \pm 0.08^{\mathrm{d}}$ & $<1.0$ & $<1.0$ & $<1.0$ & $<1.0$ \\
14 & $6.88 \pm 0.02^{\mathrm{b}}$ & $16.05 \pm 0.22^{\mathrm{a}}$ & $0.23 \pm 0.01^{\mathrm{ab}}$ & $3.43 \pm 0.09^{\mathrm{b}}$ & $<1.0$ & $<1.0$ & $<1.0$ & $<1.0$ \\
21 & $6.84 \pm 0.01^{\mathrm{c}}$ & $15.30 \pm 0.22^{\mathrm{abc}}$ & $0.14 \pm 0.03^{\mathrm{b}}$ & $2.70 \pm 0.01^{\mathrm{d}}$ & $<1.0$ & $<1.0$ & $<1.0$ & $<1.0$ \\
28 & $6.86 \pm 0.01^{\mathrm{bc}}$ & $15.63 \pm 0.29^{\mathrm{ab}}$ & $0.29 \pm 0.08^{\mathrm{a}}$ & $2.29 \pm 0.08^{\mathrm{e}}$ & $<1.0$ & $<1.0$ & $<1.0$ & $<1.0$ \\
35 & $6.88 \pm 0.02^{\mathrm{b}}$ & $14.12 \pm 0.14^{\mathrm{d}}$ & $0.14 \pm 0.01^{\mathrm{b}}$ & $3.56 \pm 0.04^{\mathrm{b}}$ & $5.63 \pm 0.03^{\mathrm{b}}$ & $5.25 \pm 0.02^{\mathrm{a}}$ & $<1.0$ & $<1.0$ \\
42 & $6.90 \pm 0.01^{\mathrm{b}}$ & $15.13 \pm 0.14^{\mathrm{bc}}$ & $0.18 \pm 0.01^{\mathrm{ab}}$ & $4.16 \pm 0.03^{\mathrm{a}}$ & $5.96 \pm 0.04^{\mathrm{a}}$ & $5.29 \pm 0.01^{\mathrm{a}}$ & $<1.0$ & $<1.0$ \\
\hline \hline
\end{tabular}

* The means with different letters in the same column are significantly different $(\mathrm{P}<0.05)$.

Microbiological evaluations are one of the important quality parameters used in seafood. The microbiological load is under the influence of many factors. The limit value for aerobic bacteria is accepted as $7 \log \mathrm{cfu} / \mathrm{g}$ (ICMSF, 1986). The number of total mesophilic aerobic bacteria (TMAB), total psychrophilic aerobic bacteria (TPAB), lactic acid bacteria, and yeast-mold in raw meagre fish is $6.29 \pm 0.13 \mathrm{log} \mathrm{cfu} / \mathrm{g}, 6.43 \pm 0.00 \mathrm{log} \mathrm{cfu} / \mathrm{g}, 4.16 \pm 0.01 \mathrm{log} \mathrm{cfu} / \mathrm{g}$, and $5.63 \pm 0.05 \mathrm{log} \mathrm{cfu} / \mathrm{g}$, respectively (Tablo 3, 4, 5). In vacuum-packed products, the proliferation of aerobic bacteria is prevented since there is no air in the package (Gülyavuz and Ünlüsayın, 1999). It has been observed that the heat treatment used in sous vide application is effective on TMAB, TPAB, lactic acid bacteria, yeast and mold. The sous vide method at different temperatures and times has been applied to the O. mykiss (Gonzalez-Fandos et al., 2004) and S. salar (Gonzalez-Fandos et al., 2005) and it has been stated that the applied heat treatment is effective on the bacteria. Alt1kaya (2016), applied sous vide technique at three different temperatures $\left(60^{\circ} \mathrm{C}, 70^{\circ} \mathrm{C}\right.$, and $\left.80^{\circ} \mathrm{C}\right)$ to the Sander lucioperca, and stated that the TMAB value in the fresh sample decreased with the application of sous vide process. Kenar et al. (2010), in a study on the antimicrobial and antioxidant effects of rosemary and sage extracts, it was found that the total number of bacteria increased in all groups in vacuum packed sardine fillets stored at $3{ }^{\circ} \mathrm{C}$, but the increase in the control group developed faster. Hać-Szymańczuk et al. (2011) found that dried rosemary increased the number of mesophilic aerobic bacteria depending on the initial load. Bolat et al. (2019), at the end of storage (59 day) of control, laurel and curcuma sous vide, determined for TMAB count $2.85 \pm 0.53 \log \mathrm{cfu} / \mathrm{g}, 6.30 \pm 0.32 \mathrm{log} \mathrm{cfu} / \mathrm{g}$ and $6.01 \pm 0.02 \log \mathrm{cfu} / \mathrm{g}$, for TPAB count $4.00 \pm 2.32 \log \mathrm{cfu} / \mathrm{g}, 6.12 \pm 0.42 \mathrm{log} \mathrm{cfu} / \mathrm{g}$ and $5.75 \pm 0.30 \mathrm{log} \mathrm{cfu} / \mathrm{g}$, respectively. In the Control SV, Rosemary SV and Oregano SV samples, the number of total mesophilic aerobic bacteria and total psychrophilic aerobic bacteria on the $42^{\text {nd }}$ day did not exceed the limit values. Lactic acid bacteria and yeast-mold were not detected in all sous vide groups during storage.

Sensory evaluation is one of the most important analyzes used to determine whether a product is suitable for consumption. Sensory analyzes to be made beforehand are important. Because the final product is evaluated by consumers according to its sensory quality (Huss, 2007). Sensory features contribute greatly to the acceptance of sous vide products. Sous vide products have the flavour closest to fresh produce (Garcia-Linares et al., 2004). Considering all the sensory parameters, it was 
determined that the panelists initially liked the Rosemary SV and Oregano SV samples more than the Control SV samples (Table 6). In this study, similar to the studies conducted by Kenar et al. (2010) and Amariei et al. (2016), the samples that applied plant extract were generally appreciated in terms of odour. Similar to the Nissen et al. (2004), Kenar et al. (2010), and Çetinkaya (2013) studies, it was determined that the plant extract application improved the taste values.

Table 6. Sensory evaluation of Control SV, Rosemary SV and Oregano SV samples*

\begin{tabular}{|c|c|c|c|c|}
\hline & Day & Control SV & Rosemary SV & Oregano SV \\
\hline \multirow{7}{*}{$\frac{\vdots}{3}$} & 0 & $7.38 \pm 0.73^{\mathrm{ab}}$ & $8.25 \pm 0.70^{\mathrm{a}}$ & $8.50 \pm 0.63^{\mathrm{a}}$ \\
\hline & 7 & $7.75 \pm 0.41^{\mathrm{a}}$ & $7.13 \pm 0.48^{\mathrm{ab}}$ & $7.63 \pm 0.68^{\mathrm{ab}}$ \\
\hline & 14 & $6.38 \pm 0.32^{\mathrm{abc}}$ & $6.75 \pm 0.31^{\mathrm{b}}$ & $6.38 \pm 0.26^{\mathrm{bc}}$ \\
\hline & 21 & $6.25 \pm 0.41^{\mathrm{bc}}$ & $6.88 \pm 0.23^{\mathrm{ab}}$ & $6.38 \pm 0.42^{\mathrm{bc}}$ \\
\hline & 28 & $5.75 \pm 0.45^{\mathrm{c}}$ & $6.00 \pm 0.46^{\mathrm{b}}$ & $5.88 \pm 0.44^{\mathrm{c}}$ \\
\hline & 35 & $5.50 \pm 0.46^{\mathrm{c}}$ & $6.13 \pm 0.55^{b}$ & $5.88 \pm 0.52^{\mathrm{c}}$ \\
\hline & 42 & $4.13 \pm 0.30^{\mathrm{d}}$ & $3.50 \pm 0.42^{\mathrm{c}}$ & $3.25 \pm 0.41^{\mathrm{d}}$ \\
\hline \multirow{7}{*}{$\stackrel{\vdots}{0}$} & 0 & $7.50 \pm 0.50^{\mathrm{a}}$ & $8.00 \pm 0.53^{\mathrm{a}}$ & $8.50 \pm 0.63^{\mathrm{ab}}$ \\
\hline & 7 & $5.88 \pm 0.69^{\mathrm{b}}$ & $7.13 \pm 0.67^{\mathrm{ab}}$ & $8.88 \pm 0.48^{\mathrm{a}}$ \\
\hline & 14 & $5.75 \pm 0.31^{\mathrm{b}}$ & $6.38 \pm 0.42^{\mathrm{b}}$ & $7.88 \pm 0.44^{\mathrm{ab}}$ \\
\hline & 21 & $5.63 \pm 0.42^{\mathrm{b}}$ & $6.63 \pm 0.18^{\mathrm{ab}}$ & $7.38 \pm 0.32^{\mathrm{ab}}$ \\
\hline & 28 & $5.00 \pm 0.38^{\mathrm{bc}}$ & $6.50 \pm 0.42^{\mathrm{b}}$ & $7.50 \pm 0.33^{\mathrm{ab}}$ \\
\hline & 35 & $3.75 \pm 0.70^{\mathrm{cd}}$ & $6.25 \pm 0.25^{\mathrm{b}}$ & $7.13 \pm 0.35^{\mathrm{b}}$ \\
\hline & 42 & $2.38 \pm 0.38^{\mathrm{d}}$ & $3.88 \pm 0.55^{\mathrm{c}}$ & $4.88 \pm 0.67^{\mathrm{c}}$ \\
\hline \multirow{7}{*}{ 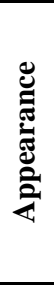 } & 0 & $7.50 \pm 0.73^{\mathrm{a}}$ & $8.38 \pm 0.53^{\mathrm{a}}$ & $8.38 \pm 0.60^{\mathrm{a}}$ \\
\hline & 7 & $7.63 \pm 0.42^{\mathrm{a}}$ & $7.38 \pm 0.46^{\mathrm{ab}}$ & $8.00 \pm 0.63^{\mathrm{ab}}$ \\
\hline & 14 & $6.25 \pm 0.31^{\mathrm{ab}}$ & $6.88 \pm 0.35^{\mathrm{b}}$ & $6.25 \pm 0.45^{\mathrm{c}}$ \\
\hline & 21 & $6.25 \pm 0.45^{\mathrm{ab}}$ & $6.50 \pm 0.42^{\mathrm{b}}$ & $6.88 \pm 0.48^{\mathrm{bc}}$ \\
\hline & 28 & $5.88 \pm 0.48^{\mathrm{b}}$ & $6.63 \pm 0.18^{b}$ & $6.50 \pm 0.19^{c}$ \\
\hline & 35 & $5.63 \pm 0.42^{\mathrm{b}}$ & $6.50 \pm 0.46^{\mathrm{b}}$ & $6.63 \pm 0.42^{\mathrm{bc}}$ \\
\hline & 42 & $4.13 \pm 0.30^{\mathrm{c}}$ & $3.38 \pm 0.42^{\mathrm{c}}$ & $3.63 \pm 0.46^{\mathrm{d}}$ \\
\hline \multirow{7}{*}{ } & 0 & $8.50 \pm 0.50^{\mathrm{a}}$ & $8.75 \pm 0.37^{\mathrm{a}}$ & $9.00 \pm 0.38^{\mathrm{a}}$ \\
\hline & 7 & $6.50 \pm 0.46^{\mathrm{b}}$ & $7.88 \pm 0.64^{\mathrm{ab}}$ & $8.63 \pm 0.38^{\mathrm{a}}$ \\
\hline & 14 & $5.75 \pm 0.49^{b}$ & $7.00 \pm 0.27^{\mathrm{bc}}$ & $7.00 \pm 0.42^{\mathrm{b}}$ \\
\hline & 21 & $6.00 \pm 0.42^{b}$ & $7.25 \pm 0.25^{\mathrm{bc}}$ & $7.00 \pm 0.38^{\mathrm{b}}$ \\
\hline & 28 & $5.38 \pm 0.38^{\mathrm{b}}$ & $6.75 \pm 0.16^{\mathrm{bc}}$ & $6.88 \pm 0.35^{\mathrm{b}}$ \\
\hline & 35 & $5.13 \pm 0.44^{\mathrm{b}}$ & $6.25 \pm 0.31^{\mathrm{c}}$ & $5.75 \pm 0.53^{\mathrm{b}}$ \\
\hline & 42 & $2.63 \pm 0.50^{\mathrm{c}}$ & $3.38 \pm 0.42^{\mathrm{d}}$ & $3.88 \pm 0.52^{\mathrm{c}}$ \\
\hline \multirow{7}{*}{ } & 0 & $7.50 \pm 0.50^{\mathrm{a}}$ & $8.88 \pm 0.44^{\mathrm{a}}$ & $8.50 \pm 0.50^{\mathrm{a}}$ \\
\hline & 7 & $6.88 \pm 0.48^{\mathrm{ab}}$ & $8.13 \pm 0.52^{\mathrm{ab}}$ & $8.25 \pm 0.73^{\mathrm{a}}$ \\
\hline & 14 & $5.63 \pm 0.89^{b c}$ & $7.13 \pm 0.13^{b c}$ & $7.88 \pm 0.44^{\mathrm{ab}}$ \\
\hline & 21 & $6.00 \pm 0.42^{\mathrm{abc}}$ & $7.13 \pm 0.23^{b c}$ & $7.25 \pm 0.31^{\mathrm{ab}}$ \\
\hline & 28 & $5.75 \pm 0.45^{\mathrm{bc}}$ & $6.75 \pm 0.16^{\mathrm{cd}}$ & $7.50 \pm 0.46^{\mathrm{ab}}$ \\
\hline & 35 & $5.00 \pm 0.46^{\mathrm{c}}$ & $5.88 \pm 0.35^{\mathrm{d}}$ & $6.25 \pm 0.62^{\mathrm{b}}$ \\
\hline & 42 & $2.63 \pm 0.42^{\mathrm{d}}$ & $3.50 \pm 0.38^{\mathrm{e}}$ & $3.50 \pm 0.60^{\mathrm{c}}$ \\
\hline \multirow{7}{*}{ 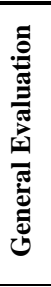 } & 0 & $7.75 \pm 0.45^{\mathrm{a}}$ & $8.63 \pm 0.56^{\mathrm{a}}$ & $8.75 \pm 0.53^{\mathrm{a}}$ \\
\hline & 7 & $7.25 \pm 0.31^{\mathrm{ab}}$ & $7.88 \pm 0.44^{\mathrm{ab}}$ & $8.63 \pm 0.53^{\mathrm{ab}}$ \\
\hline & 14 & $6.25 \pm 0.37^{\mathrm{bc}}$ & $6.75 \pm 0.31^{\mathrm{c}}$ & $7.00 \pm 0.38^{c}$ \\
\hline & 21 & $6.13 \pm 0.30^{c}$ & $7.25 \pm 0.25^{\mathrm{bc}}$ & $7.38 \pm 0.32^{b c}$ \\
\hline & 28 & $5.38 \pm 0.32^{\mathrm{c}}$ & $7.00 \pm 0.00^{\mathrm{bc}}$ & $7.13 \pm 0.35^{\mathrm{c}}$ \\
\hline & 35 & $5.13 \pm 0.48^{\mathrm{c}}$ & $6.50 \pm 0.27^{\mathrm{c}}$ & $6.50 \pm 0.46^{\mathrm{c}}$ \\
\hline & 42 & $2.88 \pm 0.35^{\mathrm{d}}$ & $3.75 \pm 0.31^{\mathrm{d}}$ & $3.75 \pm 0.56^{\mathrm{d}}$ \\
\hline
\end{tabular}

*The means with different letters in the same column are significantly different $(\mathrm{P}<0.05)$

\section{CONCLUSIONS}

Today, natural plant products that preserve the quality and enrich the sensory properties are used instead of synthetic additives in sous vide technology. In our country, where fresh fish consumption is at the forefront compared to processed products, it has been observed that the meagre fish can be evaluated with the sous vide processing method. Sous vide meagre fillet is thought to have an alternative processed product and also nutritional value in terms of the fatty acids it contains. This 
study determined that $\mathrm{pH}$, TVB-N, TMA-N and TBA values of sous vide sample groups did not exceed the deterioration limit values during cold storage. It was observed that the TVB-N and TBA values of the samples treated with oregano and rosemary extract were lower than the control sous vide group samples. Although the limit values for TMAB and TPAB are not exceeded and lactic acid bacteria, yeast and mold are not found at the end of the storage period in sous vide samples, pathogen microorganism control should be done for food safety. It can be said that panelists appreciated the sous vide meagre fillets. It has been determined that the extracts of oregano and rosemary, which are used as natural additives, also improve the sensory quality of the product.

Acknowledgments: This study was summarized from the Ph.D. Thesis, which was financially supported by the project number 5087-D1-17 of Süleyman Demirel University Scientific Research Projects Coordination Unit.

\section{REFERENCES}

Altıkaya, Ş. E. (2016). Farklı Sicaklıklarda Sous Vıde Uygulanmış Sudak Balığının (Sander lucioperca Linnaeus, 1758) Raf Ömrü Üzerine Bir Araştırma. Yüksek Lisans Tezi, Recep Tayyip Erdoğan Üniversitesi, Fen Bilimleri Enstitüsü. [in Turkish].

Altuğ, T., \& Elmac1, Y. (2005). Gldalarda Duyusal Değerlendirme (Sensory Evaluation in Foods). İzmir, Meta Basım Matbacılık Hizmetleri. 115 s. [in Turkish].

Amariei, S., Poroch-Seriţan, M., Gutt, G., Oroian, M., \& Ciornei, E. (2016). Rosemary, thyme and oregano essential oils influence on physicochemical properties and microbiological stability of minced meat. Journal of Microbiology, Biotechnology and Food Scicience, 6 (1), 670-676. http://doi.org/doi: 10.15414/jmbfs.2016.6.1.670-676

AOAC. (2000). Offical methods of analysis. Association of Offical Analytical Chemists, USA. Offical methods of analysis.

AOAC. (2002a). Offical methods of analysis. Association of Offical Analytical Chemists USA. Offical methods of analysis.

AOAC. (2002b) 996.06. Fat (total, saturated, and unsaturated) in foods. Hydrolytic extraction gas chromatographic method, Official Methods of Analysis of AOAC International. Offical methods of analysis, USA.

Arslan, A., Çelik, C., Ateş, G., Kök, A., \& Kaya, A. (1997). Analysis of microbiological and chemical qualities of vacuumed and unvacuumed mirror carp (Cyprinus carpino L.) pastrami. Turkish Journal of Veterinary and Animal Sciences, 21, 23-29.

Baydar, H. (2013). Tibbr Aromatik Bitkiler Bilimi ve Teknolojisi (Medicine and Aromatic Plants Science and Technology). Isparta, Süleyman Demirel Üniversitesi Yayınları. [in Turkish].

BCCDC (BC Centre for Disease Control) (2016). Guidelines for Restaurant Sous Vide Cooking Safety in British Columbia.

http://www.bccdc.ca/resourcegallery/Documents/Guidelines\%20and\%20Forms/Guidelines\%20and\%20Manuals/EH/FPS/Food/SVGuid elines_FinalforWeb.pdf (Last access date: 06.05.2018).

Beauchemin, M. (1990). Sous-vide technology. American Meat Science Association, 43, 103-107. https://meatscience.org/docs/default-source/publications-resources/rmc/1990/sous-videtechnology.pdf?sfvrsn=2

Betts, G.D., \& Gaze, J.E. (1995). Growth and heat resistance of psychrotrophic Clostridium botulinum in relation to 'sous vide' products. Food Control, 6(1), 57-63.

Bilgin, Ş., İzci, L., Günlü, A., Diken, G., \& Genç, İ.Y. (2016). Effects of gutting process on the shelf life of cultured sarıăız balığı (Argyrosomus regius Asso, 1801) stored at $4 \pm 1{ }^{\circ} \mathrm{C}$. Food Science and Technology, Campinas, 36(2), 344-350.

Bligh, E. G., \& Dyer, W.J. (1959). A rapid method of total lipid extraction and purification. Canadian Journal of Biochemistry and Physiology, 37(8), 911-917.

Bodur, T. (2018). Sarıă̆ız (Argyrosomus regius, Asso 1801) balığının toprak havuzlarda ticari yetiştiriciliğinde bazı büyüme parametrelerinin belirlenmesi. Süleyman Demirel Üniversitesi Eğirdir Su Ürünleri Fakültesi Dergisi, 14(3), 232-240. [in Turkish].

Bolat, Y., Genç, İ.Y., Tunca, Y., Demirayak, M. (2019). Effect of laurel (Laurus nobilis) and curcuma (Curcuma longa) on microbiological, chemical and sensory changes in vacuum packed sous-vide european sea bass (Dicentrarchus labrax) under chilled conditions. Food Science and Technology, Campinas, 39 (Suppl.1), 159-165.

Bozkurt, H. (2006). Utilization of natural antioxidants: green tea extract and Thymbra spicata oil in Turkish dryfermented sausage. Meat Science, 73(3), 442-450. 
BSGM (Balıķılık ve Su Ürünleri Genel Müdürlüğü) 2020. Su Ürünleri İstatistikleri. https://www.tarimorman.gov.tr/BSGM/Belgeler/Icerikler/Su\%20\%C3\%9Cr\%C3\%BCnleri\%20Veri\%20v e\%20D\%C3\%B6k\%C3\%BCmanlar\%C4\%B1/Su-\%C3\%9Cr\%C3\%BCnleri-\%C4\%B0statistikleri.pdf (Last Access date:10.02.2021). [in Turkish].

Connell, J. J. (1995). Control of fish quality (4th ed.). London: Fishing New Books Limited. Control of fish quality (4th ed.). London: Fishing New Books Limited.

Çetinkaya, S. (2013). Vakum Paketli Pişirilen (Sous Vide) Gökkuşağı Alabalı̆̆ (Oncorhynchus mykiss Walbaum, 1792)'nın Soğuk Depolanması Sirasında Kalite Özelliklerine Doğal Antioksidanların Etkisi. (Doktora Tezi, Süleyman Demirel Üniversitesi, Fen Bilimleri Enstitüsü). [in Turkish].

Çetinkaya. S., Bilgin. Ş., Ertan. Ö.O., \& Bilgin. F. (2015). Vakum paketli pişirme yöntemi (sous vide) ve gökkuşağı alabalığı (Oncorchynchus mykiss Walbaum, 1792)'na uygulanması. Ĕgirdir Su Ürünleri Fakültesi Dergisi, 11(2):35-44. [in Turkish].

Diaz, P., Nieto, G., Banon, S., \& Garrido, M.D. (2009). Determination of shelf life of sous vide salmon (Salmo salard) based on sensory attributes. Journal of Food Science, 74 (8), 371-376.

Doğruyol, H., \& Mol, S. (2016). Effect of irradiation on shelflife and microbial quality of cold-stored sous-vide mackerel fillets. Journal of Food Processing and Preservation, 41(2), 1-8.

El-Hanafy, A.E.A., Shawky, H.A., \& Ramadan, M.F. (2011). Preservation of Oreochromis Niloticus fish using frozen green tea extract: impact on biochemical, microbiological and sensory characteristics. Journal of Food Processing and Preservation, 35(5), 639-646.

Erkan, N. \& Özden, Ö. (2008). Quality assessment of whole and gutted Sardines (Sardina pilchardus) stored in ice. International Journal of Food Science and Technology, 43(9), 1549-1559.

Erkan, N., Tosun, Ş.Y., Alakavuk, D.U. \& Ulusoy, Ş. (2009). Keeping quality of different packaged salted atlantic bonito "Lakerda". Journal of Food Biochemistry, 33(5), 728-744.

Espinosa, M.C., Díaz, P., Linares, M.B., Teruel, M.R., \& Garrido, M.D.G. (2015). Quality characteristics of sous vide ready to eat seabream processed by high pressure. Food Science and Technology, 64(2), 657-662.

FAO (Food and Agriculture Organization of the United Nations) (2020). The State of World Fisheries and Aquaculture 2020. Sustainability in action. Rome. https://doi.org/10.4060/ca9229en

Fountoulaki, Grigorakis, K., Kounna, C., Rigos, G., Papandroulakis, N., Diakogeorgakis, J., \& Kokou, F. (2017). Growth performance and product quality of sarıăız balığı (Argyrosomus regius) fed diets of different protein/lipid levels at industrial scale. Italian Journal of Animal Science, 16(4), 685-694.

Gao, M., Feng, L., Jiang, T., Zhu, J., Fu, L., Yuan, D., \& Li, J. (2014). The use of rosemary extract in combination with nisin to extend the shelf life of pompano (Trachinotus ovatus) fillet during chilled storage. Food Control, 37, 1-8.

Garcia-Linares, M.C., Gonzalez-Fandos, E., García-Fernández, M.C., \& García-Arias, M.T. (2004). Microbiological and nutritional quality of sous vide or traditionally processed fish: influence of fat content. Journal of Food Quality, 27(5), 371-387.

Genç, İ.Y., Esteves, E., Aníbal, J., \& Diler, A. (2013). Effects of chilled storage on quality of vacuum packed meagre fillets. Journal of Food Engineering, 115(4), 486-494.

Giacometti, J., Kovačević, D.B., Putnik, P., Gabrić, D., Bilušić, T., Krešić, G., Stulić, V., Barbae, F.J., Chemat, F., Barbosa-Cánovas, G., \& Jambrak, A.R. (2018). Extraction of bioactive compounds and essential oils from mediterranean herbs by conventional and green innovative techniques: A review. Food Research International, 113 (2018) 245-262.

Giogios, I, Grigorakis, K., \& Kalogeropoulos, N. (2013). Organoleptic and chemical quality of farmed sarıăız balığı (Argyrosomus regius) as affected by size. Food Chemistry, 141(3), 3153-3159.

Gonzalez-Fandos, E., Garcia-Linares, M.C., Villarino-Rodriguez, A., Garcia-Arias, M.T., \& Garcia-Fernandez, M.C. (2004). Evaluation of the microbiological safety and sensory quality of rainbow trout (Oncorhynchus mykiss) processed by the Sous Vide Method. Food Microbiology, 21(2), 193-201.

Gonzalez-Fandos, E., Villarino-Rodriguez, A., Garcia-Linares, M.C., Garcia-Arias, M.T., \& Garcia-Fernandez, M.C. (2005). Microbiological safety and sensory characteristics of salmon slices processed by the sous vide method. Food Control, 16(1), 77-85.

Grigorakis, K., Fountoulaki, E., Vasilaki, A., Mittakos, I., \& Nathanailides, C. (2011). Lipid quality and filleting yield of reared sarıăız balığı (Argyrosomus regius). International Journal of Food Science \& Technology, 46(4),711-716.

Gülyavuz, H. \& Ünlüsayın, M. (1999). Su Ürünleri Isşleme Teknolojisi. Süleyman Demirel Üniversitesi Egirdir Su Ürünleri Fakültesi Ders Kitabı, Sahin Matbaası. [in Turkish].

Hać-Szymańczuk, E., Lipińska, E., \& Stasiuk, M. (2011). The effect of rosemary preparations on the microbial quality and TBARS value of model pork batters. Acta Sci Pol Technol Aliment, 10(2), 165-174.

Harrigan, W.F. \& McCance, M.E. (1976). Laboratory Methods in Food And Dairy Microbiolgy. London 
Hernandez, M.D., López, M.B., Álvarez, A., Ferrandini, E., García, B.G. \& Garrido, M.D. (2009). Sensory, physical, chemical and microbiological changes in aquacultured meagre (Argyrosomus regius) fillets during ice storage. Food Chemistry, 114(1), 237-245.

Holley, R.A., \& Patel, D. (2005). Improvement in shelf-life and safety of perishable foods by plant essential oils and smoke antimicrobials. Food Microbiology, 22(4), 273-292.

Huss, H.H. (2007). Taze Balıkta Kalite ve Kalite Değişimleri. Çeviri: Çelik M., Küçükgülmez A. Roma, FAO Balıkçılık Teknik Not: 348. 195 s. [in Turkish].

ICMSF (International Commission on Microbiological Specifications for Foods), (1986). Sampling plans for fish and shellfish. In: International Commission on Microbiological Specifications for Foods - ICMFS (Ed.), Microorganisms in foods. Sampling for microbiological analysis: principles and scientific applications (2nd ed., pp. 181-196). Toronto: University of Toronto Press.

Ibarra, J.P., Teixeira, A., Simpson, R., Valencia, P., Pinto, M., \& Almonasit, S. (2013). Addition of Fish protein hydrolysate for enhanced water retention in sous vide processing of salmon. Journal of Food Process Technology, 4(7), 1-7.

İnanli A.G., Yaz Y. (2020). Assessment of chemical, microbiological and sensory quality of Sous vide cooked Luciobarbus esocinus (Heckel, 1843) during chilled storage. Progress in Nutrition, 22(2), 617-625.

Kato, H.C.A., Peixoto Joeleb, M.R.S., Sousaa, C.L., Ribeirob, S.C.A., \& Lourençoc, L.F.H. (2017). Evaluation of the Shelf Life of Tambaqui Fillet Processed by the Sous Vide Method. Journal of Aquatıc Food Product Technology, 26(10), 1144-1156.

Kenar M., Özoğul F., \& Kuley E. (2010). Effects of rosemary and sage tea extracts on the sensory, chemical and microbiological changes of vacuum-packed and refrigerated sardine (Sardina pilchardus) fillets. International Journal of Food Science and Technology, 45(11), 2366-2372.

Lagouri, V., \& Boskou, D. (1996). Nutrient antioxidants in oregano. International Journal of Food Science and Nutrition, 47(6), 493-497.

Martelli, R., Zotte, A.D., Bonelli, A., Lupi, P., Franci, O., \& Parisi, G. (2013). Macronutrient and fatty acid (Argyrosomus regius) fillets profiles of meagre as influenced by harvesting time and boiling. Italian Journal of Animal Science, 12(88), 538-545.

Mesa, S.G, Suárez, M.D., Rincón Cervera, M.A., Guil Guerrero, J.L., González, G., Cárdenas, S. \& García Gallego, M. (2014). Time course of muscle fatty acid composition of cultured meagre (Argyrosomus regius) during the first sixteen months of a cage culture. Grasas Aceites, 65(1), 1-9.

Mol, S., \& Özturan, S. (2009). Sous-vide teknolojisi ve su ürünlerindeki uygulamalar. Journal of Fisheries Sciences, 3(1), 68-75.

Mol, S., Özturan, S., \& Cosansu, S. (2012). Determination of the quality and shelf life of sous vide packaged bonito (Sarda Sarda, Bloch, 1793) stored at 4 and $12^{\circ}$ C. Journal of Food Quality, 35(2), 137-143.

Monfort, M.C. (2010). Present market situation and prospects of sarıăız balığı (Argyrosomus regius), as an emerging species in Mediterranean aquaculture, Food and Agriculture Organization of The United Nations, http://www.fao.org/docrep/013/i1675e/i1675e.pdf (Last access date: 27.05.2019).

Nicholas, T. A. (2003). Antimicrobial Use of Native and Enzymatically Degraded Chitosans for Seafood Aplications. (MSc. Thesis, The University of Maine, Maine).

Nieva-Echevarria, B., Manzanos, M.J., Goicoechea, E. \& Guillén, M.D. (2017). Changes provoked by boiling, steaming and sous-vide cooking in the lipid and volatile profile of European sea bass. Food Research International, 99(1), 630-640.

Nissen, L. R., Byrne, D.V., Bertelsen, G., \& Skibsted, L. H. (2004). The antioxidative activity of plant extracts in cooked pork patties as evaluated by descriptive sensory profiling and chemical analysis. Meat Science, 68(3), 485-495.

NSW, 2018. Food Authority, NSW Government, Sous Vide Food Safety Precautions for Restaurants. http://www.foodauthority.nsw.gov.au/_Documents/scienceandtechnical/sous_vide_food_safey_precautio ns.pdf. (Last access date: 06.05.2018).

Öksüz, A., Alkan, Ş.B., Taşkın, H., \& Ayranc1, M. (2017). Yaşam boyu sağlıklı ve dengeli beslenme için balık tüketiminin önemi. Food and Health, 4(1), 43-62. [in Turkish].

Özden, Ö., \& Erkan, N. (2006). Effect of different packing methods on the shelf life of marinated rainbow trout. Archiv fur Lebensmittelhygiene. 57, 69-75.

Ramos F.C.P, Lourenço L.F.H., Joele M.R.S.P., Lima C.L.S., \& Riberio S.C.A. (2016) Tambaqui (Colossoma macropomum) sous vide: characterization and quality parameters. Semina Ciências Agrárias, 37(1), 117130.

Ruiz-Capillas, C., \& Moral, A. (2001). Correlation between biochemical and sensory quality indices in hake stored in ice. Food Research International, 34, 441-447. 
Saavedra, M., Pereira, T.G., Grade, A., Barbeiro, M., Pousao-Ferreira, P., Quental-Ferreira, H., Nunes, M.L., Bandarra, N., \& Gonçalves, A. (2015). Farmed meagre ( Argyrosomus regius) of three different sizes: what are the differences in flesh quality and muscle cellularity?. International Journal of Food Science and Technology, 50(6), 1311-1316.

Schellekens, M. (1996). New research issues in sous-vide cooking. Trends in Food Science \& Technology, 7(8), 256-262.

Schormüller, J. (1968). Tierische Lebensm. Eier. Fleisch. Buttermilsch. In Handbuch der Lebensmittel Chemie, Band III/2 Teil. Berlin-Hiedelberg. New York, Springer-Verlag.

Sebranek, J. G., Sewalt, V. J. H., Robbins, K. L., \& Houser, T. A. (2005). Comparison of a natural rosemary extract and BHA/BHT for relative antioxidant effectiveness in pork sausage. Meat Science, 69(2), 289296.

Tironi V.A., Tomas M.C., \& Anon M.C. (2010), Quality loss during the frozen storage of sea salmon (Pseudopercis semifasciata) Effect of rosemary (Rosmarinus officinalis L.) extract. Food Science and Technology, 43(2), 263-272.

Uçak, İ., Özoğul, Y., \& Durmuş, M. (2011). The effects of rosemary extract combination with vacuum packing on the quality changes of atlantic mackerel fish burgers. International Journal of Food Science and Technology, 46(6), 1157-1163.

Ufuk, D., \& Sarımehmetoğlu, B. (2016). Balık etinin muhafazasında soğutma ve dondurma yöntemleri. Erciyes Üniversitesi Veteriner Fakültesi Dergisi, 13(2), 151-158. [in Turkish].

Varlık, C., Özden, Ö., Erkan, N., \& Alakavuk, D.Ü. (2007). Su Ürünlerinde Temel Kalite Kontrol (Basic Quality Control in Seafood). İstanbul Üniversitesi Yayınları, İstanbul. [in Turkish].

Varlık, C., Uğur, M., Gökoğlu, N., \& Gün, H. (1993). Su ürünlerinde kalite kontrol ilke ve yöntemleri (Quality control principles and methods in seafood). Gıda Teknolojisi Derneği Yayınları, 17, 174 p. [in Turkish]. 